\title{
Control of Chrysodeixis includens (Lepidoptera: Noctuidae) using Chin-IA (I-A) isolate as integrate component of management in soybean crops
}

\author{
Controle de Chrysodeixis includens (Lepidoptera: Noctuidae) usando o isolado \\ Chin-IA (I-A) como componente do manejo integrado da cultura da soja
}

\author{
Ana Beatriz Riguetti Zanardo Botelho' (D), Ivana Fernandes da Silva ${ }^{2 *}$ (D), Crébio José Ávila ${ }^{3}$ (D) \\ | | | | | | | | | | | | | | | | | | | | | | | | | | | | | | | | | | | | | | | | | | | | | | | | | | | | | | | | | | | | | | | | | | | | | | | | | | | | | | | | | | | | | | | | | | | | | | | | | | | | | | | | | | | | | | | | | | | | | | | | | | | | | | | | | | | | | | | | | | | | | | | | | | | | | | | | | | | | | | | | | | | | | | | | | | | | | | | | | | | | | | | | | | | | | | | | | | | | | |
}

\begin{abstract}
Chrysodeixis includens is an important pest of soybean crop who has gained more visibility in the Brazilian Cerrado due to damage caused in this region. Foliar consumption, feeding period and mortality level of soybean loopers in laboratory, as well as their control in the field conditions, were evaluated after application of the ChinNPV virus in soybean plants. In the laboratory, were tested six concentrations of isolate Chin-IA (I-A) $\left(1 \times 10^{11}, 2 \times 10^{11}, 4 \times 10^{11}, 6 \times 10^{11}\right.$, $8 \times 10^{11}$ and $\left.10 \times 10^{11} \mathrm{PIB} \mathrm{ha}^{-1}\right)$, one dose of methomyl chemical insecticide (172 $\mathrm{g}$ ai ha-1 $^{-1}$ ) and distilled water (control). The field experiment was carried out in the 2016/2017 season using the same cultivar and laboratory treatments, except for the lowest virus concentration. The population density of small and large larvae was evaluated before and at 5, 8 and 12 days after application (DAA) of the treatments in soybean plants. All concentrations of the isolate Chin-IA (I-A) have reduced the soybean loopers consumption and their feeding period, showing $100 \%$ of mortality after $3-4$ days without differing from treatment with the chemical insecticide. After eight DAA of virus in the field, the population density of small and large larvae was reduced, providing satisfactory levels of control. These results showed the evident potential of ChinNPV in the reduction of defoliation power and maintenance the soybean loopers population under of control level, and thus may be used as complementary method in the integrated management of this pest in soybean crops.
\end{abstract}

KEYWORDS: nucleopolyhedrovirus; soybean looper; foliar consumption; population density; biological control.
RESUMO: Chrysodeixis includens é uma importante praga da cultura da soja que tem ganhado maior visibilidade na regiáo do Cerrado brasileiro em razáo do dano causado. Consumo foliar, período de alimentação e mortalidade de lagartas falsa-medideira foram avaliados em laboratório, assim como seu controle em condiçóes de campo, após a aplicação do vírus ChinNPV em plantas de soja. Em laboratório, foram testadas seis concentraçôes do isolado Chin-IA (I-A) $\left(1 \times 10^{11}, 2 \times 10^{11}, 4 \times 10^{11}, 6 \times 10^{11}, 8 \times 10^{11}\right.$ e $\left.10 \times 10^{11} \mathrm{CIP} \mathrm{ha}^{-1}\right)$, uma dose do inseticida químico metomil (172 g i.a ha-1) e água destilada (controle). O ensaio de campo foi realizado na safra 2016/2017 utilizando o mesmo cultivar e tratamentos do ensaio em laboratório, exceto para a menor concentraçáo do vírus. A densidade populacional de lagartas pequenas e grandes foi avaliada antes (pré-contagem) e 5, 8 e 12 dias após a aplicação dos tratamentos nas plantas de soja. Todas as concentraçóes do isolado Chin-IA (I-A) reduziram o consumo e o período de alimentaçáo das lagartas falsa-medideira, mostrando $100 \%$ de mortalidade entre $3-4$ dias, sem diferir do tratamento com o inseticida químico. Depois de oito dias após a aplicação do vírus no campo, a densidade populacional de lagartas pequenas e grandes foi reduzida, promovendo um controle satisfatório. Esses resultados mostram o evidente potencial de ChinNPV na redução do poder de desfolha, mantendo a população das lagartas falsa-medideira abaixo do nível de controle, e indicam o seu uso como um método complementar no manejo integrado dessa praga em culturas de soja.

PALAVRAS-CHAVE: nucleopoliedrovírus; lagartas falsa-medideira; consumo foliar; densidade populacional; controle biológico. 


\section{INTRODUCTION}

The species Chrysodeixis includens (Walker, 1857) (Lepidoptera: Noctuidae), known as soybean looper, is a polyphagous insect of a large variety leguminous plants (SPECHT et al., 2015). In Brazil, it became an important pest of soybean crop in the 2002/2003 season (SOSA-GÓMEZ et al., 2014; MOSCARDI et al., 2012), and is mainly controlled by broad spectrum chemical insecticides. The larval stage has a behavior of feeding on the leaves of the medial to lower soybean plants canopy, becoming difficult their control by insecticides which need to be applied to the bottom and inside of the plants, resulting in the necessity of higher doses of these products (DEGRANDE; VIVAN, 2008; SOSA-GÓMEZ et al., 2014). In addition, this species has been shown to be less susceptible to the active ingredients available in the market (ÁVILA et al., 2008; BERNARDI et al., 2012). Thus, the search for alternative methods to control this pest in the soybean agroecosystem is a reality.

The use of entomopathogenic virus constitutes a sustainable alternative to conventional chemical insecticides in Integrated Pest Management (IPM) programs (MOSCARDI et al., 2011; HAASE et al., 2015). The viruses of genus nucleopolyhedrovirus (NPVs) from Baculoviridae family infects different species of insects, especially those belonging to the Lepidoptera Order (THEILMANN et al., 2005; HERNIOU et al., 2012), reducing its foliar consumption and increasing the larval stage's mortality (MOSCARDI et al., 2011). Brazil presents one of the world's successful programs in the use of Baculovirus anticarsia (Anticarsia gemmatalis multiple nucleopolyhedrovirus - AgMNPV) for the control of Anticarsia gemmatalis velvetbean caterpillar (Lepidoptera: Noctuidae), which has already provided several benefits, including economic and environmental benefits to soybean crop (SOSAGÓMEZ et al., 2008).

The Chrysodeixis includens nucleopolyhedrovirus (ChinNPV: Baculoviridae) is an Alphabaculovirus pathogenic and specific to this species, previously known by the genus Pseudoplusia (CRAVEIRO et al., 2016). Due to their high specificity and natural occurrence, these viruses are good candidates for use in management programs because they are harmless to other microorganisms, natural enemies, pollinating bees, vertebrates and plants (MOSCARDI, 1990). Moreover, they are protected in protein crystals, which allows formulations with easy application technology and, hence, represents economy and biosafety in relation to the chemicals (CASTRO et al., 1999). Several aspects of ChinNPV have already been studied, including the morphology and molecular characterization of several isolates, as well as their biological activity in tests of virulence and susceptibility to different larval instars of $C$. includens $(\mathrm{BEACH}$ et al., 1987; LIVINGSTON et al., 1980; ALEXANDRE et al., 2010; CRAVEIRO et al., 2016).
The soybean crop had been a leading role in increasing the area and in the grains production in Brazil, according the latest survey performed by CONAB (2018), with an estimated current area of 35 million of hectare and production of around 114 million tons of grains. The possibility of developing the biological control of the soybean looper in this crop, using the ChinNPV virus, will provide several benefits especially for the Brazilian Cerrado region where this pest has been a serious problem. The main goal with the present study was to evaluate the effect of concentrations of an isolate [Chin-IA (IA)] from ChinNPV virus on leaf consumption, feeding period and mortality of larval stage of $C$. includens in the laboratory, and its control under field conditions.

\section{MATERIAL AND METHODS}

\section{Laboratory bioassay}

Soybean plants (Glycine max (L.), BRS 255 RR cultivar) were maintained in greenhouse at "Embrapa Agropecuária Oeste"

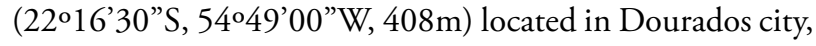
Mato Grosso do Sul state, Brazil. Leaves in the flowering period were obtained from the middle third of the plants, sterilized in sodium hypochlorite solution $(0.1 \%)$ and washed three times in distilled water. Soybean leaf discs were prepared (area of $12.56 \mathrm{~cm}^{2}$ ) and then submerged in six suspensions containing the Chin-IA (I-A) virus $\left(1 \times 10^{11}, 2 \times\right.$ $10^{11}, 4 \times 10^{11}, 6 \times 10^{11}, 8 \times 10^{11}$ and $\left.10 \times 10^{11} \mathrm{PIB} \mathrm{ha}^{-1}\right)$. A dose of the chemical insecticide methomyl (172 $\mathrm{g}$ a.i ha $\left.{ }^{-1}\right)$, recommended for the control of $C$. includens, and distilled water (control) were also used as treatments. Two discs were offered for third larval instar of $C$. includens (approximately $1.5 \mathrm{~cm}$ ) (SOSA-GÓMEZ et al., 2014) individualized in Petri dishes $(6.0 \mathrm{~cm}$ diameter $\times 1.3 \mathrm{~cm}$ height $)$ containing filter paper moistened with sterile distilled water. The bioassay was conducted in a completely randomized design with eight replicates for each treatment.

The soybean leaf area consumed was determined with a LICOR $^{\circledR}$ model LI-3000 integrator (LICOR, Inc., Lincoln, NE, USA), based on the difference between the leaf area disc initially provided and the leaf area remained after 24 hours. The mortality data in each treatment were transformed into a sine $\operatorname{arc} \sqrt{x / 100}$, submitted to variance analysis, and the average of the treatments compared by the Tukey's test at $5 \%$ probability.

\section{Field experiment}

The field experiment was performed at the full flowering stage $\left(\mathrm{R}_{2}\right)$ (RITCHIE et al., 1982) in a soybean crop containing 
the same soybean cultivar used in the laboratory bioassay described above. The area was located at the Cristalina district (22038'04”S, 5449'24”W), Caarapó municipality in Mato Grosso do Sul state, Brazil, during the 2016/2017 season. Seven treatments were considered in this experiment including five concentrations of isolate Chin-IA (I-A) $(2 \times$ $10^{11}, 4 \times 10^{11}, 6 \times 10^{11}, 8 \times 10^{11}$ and $\left.10 \times 10^{11} \mathrm{PIB} \mathrm{ha}^{-1}\right)$, one dose of the chemical insecticide methomyl (172g a.i ha $\left.{ }^{-1}\right)$ and control (without application of products). The experiment was conducted in a randomized block design with three replicates. Each replicate consisted of plots with 12 rows of soybean plants, spaced $0.45 \mathrm{~m}$ by $10.0 \mathrm{~m}$ in length $\left(54 \mathrm{~m}^{2}\right)$, having as useful area the 10 central rows in the plot. All virus treatment and the chemical were applied into soybean plants using a constant pressure bar $\left(\mathrm{CO}_{2}\right)$ sprayer equipped with empty cone nozzles and water volume equivalent to $115 \mathrm{~L} \mathrm{ha}^{-1}$.

The number of small $(\leq 1.5 \mathrm{~cm})$ and large $(>1.5 \mathrm{~cm})$ soybean loopers were evaluated before and at 5,8 and 12 days after application (DAA) of treatments in soybean plants. For the variance analysis, the average values of soybean looper (x) sampled in each plot were transformed to $\sqrt{x+0,5}$ and the means of treatments compared by the Tukey's test at 5\% of probability. The control percentage of small and large larvae in each treatment was determined using the ABBOTT formula (1925).

\section{RESULTS AND DISCUSSION}

\section{Laboratory bioassay}

In this bioassay, all six concentrations of the isolate Chin-IA (IA) tested and the methomyl had reduced significantly the soybean leaf consumption of $C$. includens in third instar, without differing from each other, when compared to larvae's consumption in the control treatment (Fig. 1). In the control, where the soybean loopers ingested soybean discs submerged only in distilled water, the average total consumption was $62.8 \mathrm{~cm}^{2}$ while the larvae from both virus and chemical insecticide treatments had a foliar consumption ranging from 11.6 and $21.5 \mathrm{~cm}^{2}$, that means a reduction of 81.5 and $65.7 \%$, respectively. The average total consumption of $C$. includens is often quite expressive in areas where no control method is employed, reaching up to $200 \mathrm{~cm}^{2}$ of soybean foliar area (TRICHILO; MACK, 1989; BUENO et al., 2012). The defoliation occurring in the reproductive period of soybean plants, in which the attack of this pest is most prominent, may reduce the grains production leading to economic damages.

The reduction in foliar area consumption found in the present study using soybean loopers in third instar was superior to that reported by ZONTA-DE-CARVALHO et al. (1991). The authors found a reduction of about $63 \%$ in the total consumption of $A$. gemmatalis after had ingested soybean leaves containing the Anticarsia gemmatalis multiple nucleopolyhedrovirus (AgMNPV) virus. In another study, larvae of Spodoptera frugiperda also from Noctuidae family had their foliar consumption reduced in $93.1 \%$ after feeding with leaves with polyhedral inclusion bodies from Spodoptera frugiperda multiple nucleopolyhedrovirus (SfNPV) (CRUZ et al., 2002). The control of defoliation insects with virus brings great advantages within the integrated management, since the population growth of these pests has been a recurring concern for soy producers in the main Brazilian states (Fig. 1).

In addition to the reduction of foliar area consumed by C. includens larvae, the feeding period was also significantly reduced in about 3 to 4 days due to mortality caused by the virus or chemical insecticide used in this experiment (Fig. 2). The mortality of $C$. includens was significantly higher in treatments in which soybean leaf discs were treated with the virus or with the chemical insecticide and offered for feeding the larvae, when compared to the control treatment, without statistically differing between them (Fig. 3). It is noteworthy that the infection progression and the multiplication of the viral particles lead to a series of behavioral and morphological changes in the insect, such as the reduction in their feeding, retardation of their growth, discoloration and rupture of the integument, culminating in their death (KATSUMA, 2015).

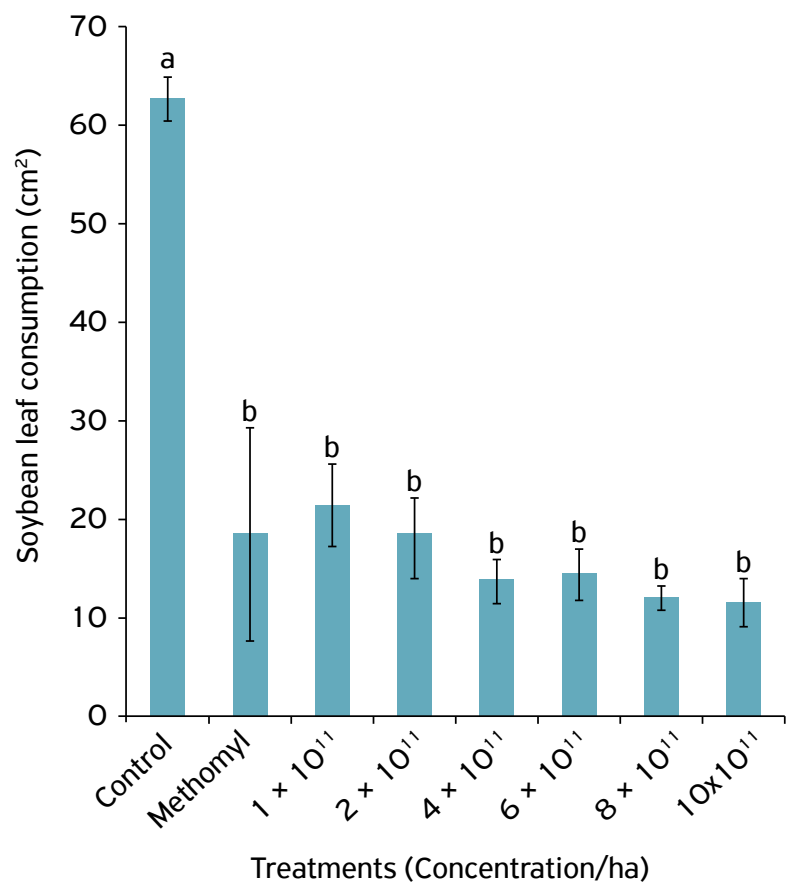

Figure 1. Average of total foliar consumption ( \pm SE) of Chrysodeixis includens larvae ( $3^{\text {rd }}$ instar) after ingestion of soybean leaf discs either submerged or not (control) into six concentrations of isolate Chin-IA (I-A) (ChinNPV) and one dose of the chemical insecticide (methomyl). 


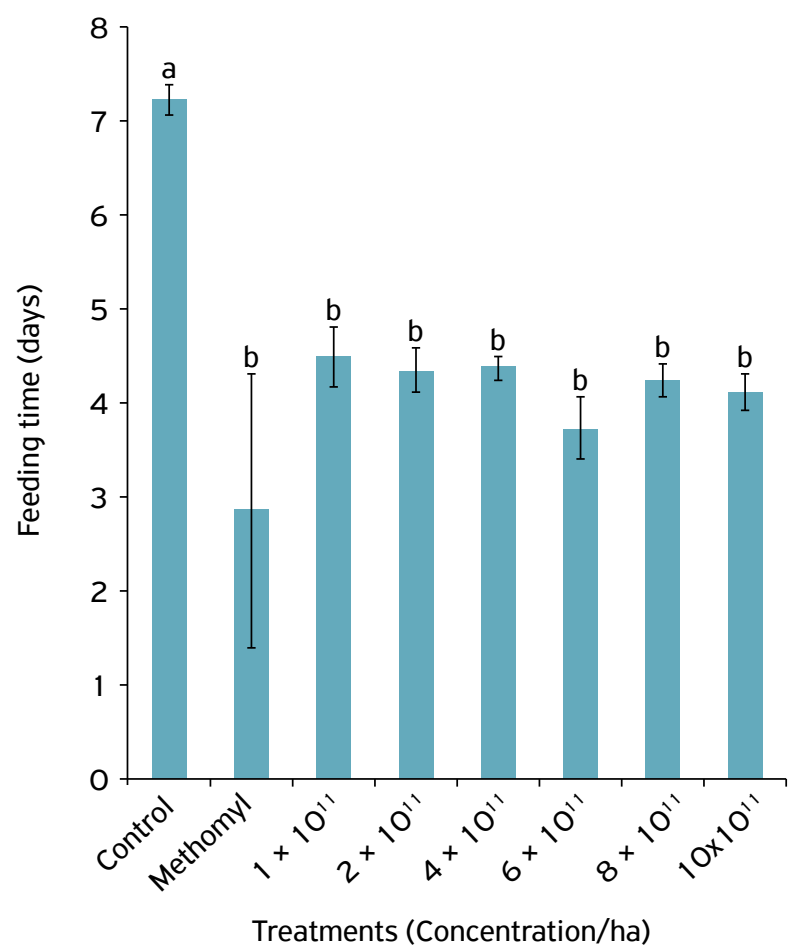

Figure 2. Average feeding time ( $\pm \mathrm{SE}$ ) of Chrysodeixis includens larvae ( $3^{\text {rd }}$ instar) after ingestion of soybean leaf discs either submerged or not (control) into six concentrations of isolate Chin-IA (I-A) (ChinNPV) and one dose of the chemical insecticide (methomyl).

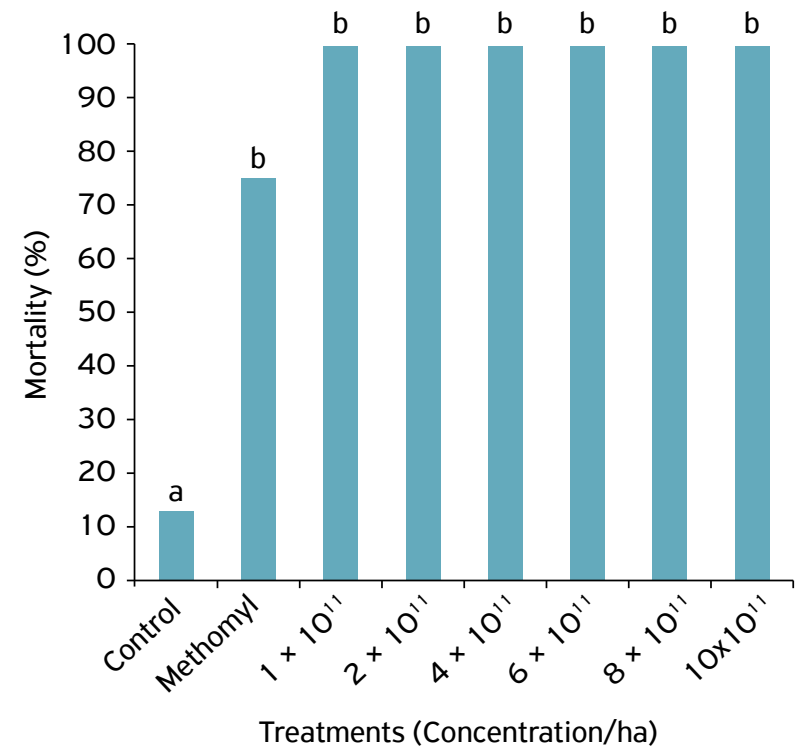

Figure 3. Mortality percentage of Chrysodeixis includens larvae ( $3^{\text {rd }}$ instar) after ingestion of soybean leaf discs either submerged or not (control) into six concentrations of isolate Chin-IA (I-A) (ChinNPV) and one dose of the chemical insecticide (methomyl).
The results presented here confirm that the use of the nucleopolyhedrovirus (NPVs) in soybean plantations constitutes an effective tool for the control of soybean looper and other lepidoptera considered as key pests in several crops. As an example of this control, we may include velvetbean caterpillar (A.gemmatalis) (MOSCARDI, 2007; SOSA-GOMÉZ et al., 2008), bollworm (Helicoverpa zea and H. armigera) (Lepidoptera: Noctuidae) (SUN; PENG, 2007; SRINIVASA et al., 2008), fall armyworm (S. frugiperda) (CRUZ et al., 2002; VALICENTE; TUELHER, 2009), the codling moth (Cydia pomonella) (Lepidoptera: Tortricidae) (LACEY; UNRUH, 2005; VINCENT et al., 2007), the gypsy moth (Lymantria dispar) (Lepidoptera: Erebidae) (COOK et al., 2003), the cassava defoliator (Erinnyis ello) (Lepidoptera: Sphingidae) (BELLOTTI et al., 1999) and the poplar caterpillar (Condylorrhiza vestigialis) (Lepidoptera: Crambidae) (CASTRO et al., 2017).

\section{Field experiment}

No significative difference was observed in the initial evaluation (before application) for the average of number of small (SL) and large (LL) larvae, with an average population density of 13.8 and 18.1 per beat cloth, respectively (Tables 1 and 2).

Regarding the small $C$. includens larvae density, it was significantly lower at $5 \mathrm{DAA}$ in the treatment with virus concentrations of $6 \times 10^{11}$ and $8 \times 10^{11}$ PIB ha $^{-1}$, methomyl chemical insecticide and control plots, without differing among each other (Table 1). At 8 DAA, the plots in which the two highest concentrations of the virus were applied had shown the lowest average number of SL and control levels above $61 \%$, differing only from the control treatment. It was to be expected since during the infection process of intestinal epithelium cells and viral multiplication, they had taken up to 6 days to cause death in $C$. includens larvae in previous studies (COX et al., 1972; BUENO et al., 2012). In small bollworm, $H$. armigera, was observed a mortality of $75 \%$ caused by HzSNPV (H. zea Single Nucleopolyhedrovirus) (KUSS et al., 2016). However, when the isolate HearNPV-MT5 (Nucleopolyhedrovirus from $H$. armigera) was used, the mortality rate was higher, being superior than $90 \%$ (SANTOS et al., 2006). Although the plots with the highest concentration of the virus provided a control level of $58.6 \%$ for SL at 12 DAA (Table 1), there was no significative difference among treatments at this evaluation date.

The average of large $C$. includens larvae number, at 5 DAA, was significantly lower in plots treated with methomyl insecticide, providing a population reduction of $54.3 \%$ (Table 2). At 8 DAA, the plots who received application of chemical insecticide and two highest concentrations of the virus had shown a significative population reduction of large larvae in the soybean plants when compared to the plots without application (control treatment), ranging from 46.7 to $59.8 \%$. 
In the last evaluation date, the four highest concentrations of the virus $\left(4 \times 10^{11}, 6 \times 10^{11}, 8 \times 10^{11}\right.$ and $10 \times 10^{11} \mathrm{PIB}$ $\mathrm{ha}^{-1}$ ) have statistically reduced the average number of large larvae in soybean plants without differing from the lowest concentration $\left(2 \times 10^{11} \mathrm{PIB} \mathrm{ha}^{-1}\right)$, achieving a control level up to $80.3 \%$. The increment of polyhedral bodies, provided by dead soybean loopers present in the soybean leaves, may have contribute with increasing control percentage found here caused by new infection cycles (PRAÇA et al., 2006; KUSS et al., 2016). It is also important mention here that soybean plants support a defoliation level of up to $15 \%$ from the flowering period until the development of the pods, and, during the period of this experiment, the defoliation level was not reached in any plot that received both the concentrations of virus and the methomyl (data not shown).

Currently, the Brazilian market has 8 commercially available baculoviruses-based biological products for the control of $A$. gemmatalis, $C$. vestigialis, $H$. armigera and S. frugiperda (AGROFIT, 2018). In addition, these microorganisms are naturally found under field conditions (CRAVEIRO et al., 2016) and can be horizontally transmitted or distributed in the environment by infected caterpillars, predators and abiotic factors such as precipitation (YOUNG; YEARIAN, 1979; PRAÇA et al., 2006; KUSS et al., 2016). Natural infections of Chrysodeixis includens nucleopolyhedrovirus (ChinNPV) in C. includens larvae were verified in soybean plantations from 2006 to 2008, in the regions of Londrina, Maringá, Iguaraçu and Sertanópolis (Paraná state), and Dourados (Mato Grosso do Sul state) (ALEXANDRE et al., 2010). In 2009 and 2010, it was also verified in Linhares (Espírito Santo state) in passion fruit orchards (BENASSI et al., 2012), and in 2014 in soybean plants in the Cerrado region of Minas Gerais state (SOUZA et al., 2015), where its high virulence and specificity were demonstrated, confirming its potential as a tool to be used to control of this pest. The isolate from ChinNPV used here are gaining increasing importance as sustainable alternative in the management programs. This virus may be easily associated with other methods of control including most of the insecticides, fungicides and fertilizers available in the market. This entomopathogenic virus is also indicated for the

Table 1. Average number of small Chrysodeixis includens larvae (SL) and control percentage (C) obtained before (pre-counting - PC) and at 5, 8 and 12 days after application (DAA) of treatments in soybean plants in Caarapó, MS, Brazil.

\begin{tabular}{|c|c|c|c|c|c|c|c|}
\hline \multirow{2}{*}{ Treatments } & \multirow{2}{*}{$\begin{array}{l}\mathrm{PC} \\
\mathrm{SL}\end{array}$} & \multicolumn{2}{|c|}{5 DAA } & \multicolumn{2}{|c|}{8 DAA } & \multicolumn{2}{|c|}{12 DAA } \\
\hline & & $\mathbf{S L} \pm \mathbf{S E}^{2}$ & $\mathrm{C}(\%)$ & $\mathrm{SL} \pm \mathrm{SE}^{2}$ & $C(\%)$ & $\mathbf{S L} \pm \mathbf{S E}^{2}$ & C (\%) \\
\hline Control & $12.3 \pm 1.7 \mathrm{~ns}^{1}$ & $13.2 \pm 0.7 a b$ & - & $14.2 \pm 1.9 a$ & - & $4.8 \pm 1.1 \mathrm{~ns}$ & - \\
\hline Methomyl & $14.0 \pm 3.8$ & $6.3 \pm 2.7 b$ & 51.9 & $8.2 \pm 1.2 a b$ & 42.4 & $9.0 \pm 3.0$ & 0.0 \\
\hline $2 \times 10^{11}$ & $12.0 \pm 3.8$ & $18.7 \pm 1.9 a$ & 0.0 & $10.3 \pm 2.6 \mathrm{ab}$ & 27.1 & $5.5 \pm 1.6$ & 0.0 \\
\hline $4 \times 10^{11}$ & $15.0 \pm 3.8$ & $19.8 \pm 3.4 \mathrm{a}$ & 0.0 & $8.5 \pm 2.2 a b$ & 40.0 & $4.5 \pm 2.0$ & 6.9 \\
\hline $6 \times 10^{11}$ & $15.7 \pm 1.7$ & $13.3 \pm 0.9 a b$ & 0.0 & $6.8 \pm 2.2 a b$ & 51.8 & $2.8 \pm 0.6$ & 41.4 \\
\hline $8 \times 10^{11}$ & $14.0 \pm 2.6$ & $14.3 \pm 2.5 a b$ & 0.0 & $5.5 \pm 1.6 b$ & 61.2 & $4.3 \pm 1.6$ & 10.3 \\
\hline $10 \times 10^{11}$ & $13.7 \pm 0.9$ & $18.5 \pm 2.0 \mathrm{a}$ & 0.0 & $4.7 \pm 0.9 b$ & 67.1 & $2.0 \pm 0.7$ & 58.6 \\
\hline
\end{tabular}

'ns = not significant in the variance analysis by the $\mathrm{F}$ test, at $5 \%$ probability; ${ }^{2}$ mean followed by the same letter in the column do not differ statistically from each other by the Tukey's test, at $5 \%$ probability.

Table 2. Average number of large Chrysodeixis includens larvae (LL) and control percentage (C) obtained before (pre-counting - PC) and at 5, 8 and 12 days after application (DAA) of treatments in soybean plants in Caarapó, MS, Brazil.

\begin{tabular}{lccccccc} 
& PC & \multicolumn{2}{c}{ 5 DAA } & \multicolumn{2}{c}{ 8 DAA } & \multicolumn{1}{c}{ 12 DAA } \\
\cline { 2 - 8 } Treatments & LL & LL \pm SE $^{2}$ & C(\%) & LL \pm SE $^{2}$ & C(\%) & LL \pm SE $^{2}$ & C(\%) \\
\hline Methomyl & $19.7 \pm 1.7 \mathrm{~ns}^{1}$ & $27.0 \pm 2.3 \mathrm{a}$ & - & $20.3 \pm 3.4 \mathrm{a}$ & - & $11.0 \pm 1.3 \mathrm{a}$ & - \\
\hline $2 \times 10^{11}$ & $17.0 \pm 3.5$ & $12.3 \pm 0.6 \mathrm{~b}$ & 54.3 & $10.8 \pm 2.5 \mathrm{bc}$ & 46.7 & $9.7 \pm 2.3 \mathrm{a}$ & 12.1 \\
\hline $4 \times 10^{11}$ & $20.0 \pm 4.6$ & $28.0 \pm 3.5 \mathrm{a}$ & 0.0 & $16.7 \pm 1.3 \mathrm{ab}$ & 18.0 & $2.2 \pm 0.3 \mathrm{~b}$ & 80.3 \\
\hline $6 \times 10^{11}$ & $16.0 \pm 3.5$ & $24.0 \pm 3.2 \mathrm{a}$ & 0.0 & $10.7 \pm 0.9 \mathrm{abc}$ & 47.5 & $3.0 \pm 0.3 \mathrm{~b}$ & 72.7 \\
\hline $8 \times 10^{11}$ & $18.7 \pm 7.7$ & $30.2 \pm 3.6 \mathrm{a}$ & 0.0 & $9.3 \pm 1.6 \mathrm{bc}$ & 54.1 & $2.2 \pm 0.7 \mathrm{~b}$ & 80.3 \\
\hline $10 \times 10^{11}$ & $17.0 \pm 1.7$ & $24.2 \pm 1.9 \mathrm{a}$ & 0.0 & $8.2 \pm 2.9 \mathrm{c}$ & 59.8 & $2.3 \pm 0.7 \mathrm{~b}$ & 78.8 \\
\hline
\end{tabular}

'ns = not significant in the variance analysis by the $\mathrm{F}$ test, at $5 \%$ probability; ${ }^{2}$ mean followed by the same letter in the column do not differ statistically from each other by the Tukey's test, at $5 \%$ probability. 
management of resistance to chemical insecticides since they preserve the natural enemies favoring the biological balance in the agroecosystem.

\section{CONCLUSION}

The isolate Chin-IA (I-A) of the ChinNPV virus reduced foliar consumption and feeding time to $3-4$ days and provided significative mortality levels of $C$. includens larvae in the laboratory bioassay. In the field conditions, there was a satisfactory reduction in the population density of small and large $C$. includens larvae from day 8 after application of treatments in soybean plants. This isolate, therefore, represents a sustainable and promising alternative to be used associated with other methods aiming the control of soybean looper in soybean crops.

\section{ACKNOWLEDGMENTS}

We thank Fundação de Apoio ao Desenvolvimento do Ensino, Ciência e Tecnologia do Estado do Mato Grosso do Sul (FUNDECT) for the financial support. This study was also financed in part by the Coordenação de Aperfeiçoamento de Pessoal de Nível Superior - Brasil (CAPES) - Finance Code 001. REFERENCES

ABBOTT, W.S. A method of computing the effectiveness of an insecticide. Journal of Economic Entomology, v. 18, p.265-267, 1925. https://doi.org/10.1093/jee/18.2.265a

AGROFIT - Sistema de agrotóxicos fitossanitários. Ministério da Agricultura, Pecuária e Abastecimento. Available from: http:// agrofit.agricultura.gov.br/agrofit_cons/principal_agrofit_cons. Accessed on: Apr. 52018.

ALEXANDRE, T.M.; RIBEIRO, Z.M.A.; CRAVEIRO, S.R.; CUNHA, F.; FONSECA, I.C.; MOSCARDI, F.; CASTRO, M.E.B. Evaluation of seven viral isolates as potential biocontrol agents against Pseudoplusia includens (Lepidoptera: Noctuidae) caterpillars. Journal of Invertebrate Pathology, v. 105, n. 1, p.98-104, 2010. https://doi.org/10.1016/j.jip.2010.05.015

ÁVILA, C.J.; SANTOS, V.; VILELA, E.F. Atração fatal. Revista Cultivar: Grandes Culturas, Pelotas, ano 9, n. 103, p.17-19, 2008.

BEACH, R.M.; STYER, E.L.; TODD, J.W. A naturally occurring nuclear polyhedrosis virus of Pseudoplusia includens in Georgia (Lepidoptera: Noctuidae). Journal of Entomological Science, v.22, n.4, p.348351, 1987. https://doi.org/10.18474/0749-8004-22.4.348

BELLOTTI, A.C.; SMITH, L.; LAPOINTE, S.L. Recent advances in cassava pest management. Annual Review of Entomology, v.44, p.343-370, 1999. https://doi.org/10.1146/annurev. ento.44.1.343

BENASSI, V.L.R.M.; VALENTE, F.I.; COMÉRIO, E.F.; CARVALHO, S. Lagarta-falsa-medideira, Pseudoplusia includens (Walker, 1857), nova praga do maracujazeiro no Espírito Santo. Revista Brasileira de Fruticultura, v.34, n.3, p.941-943, 2012. https:// doi.org/10.1590/SO100-29452012000300038

BERNARDI, O.; MALVESTITI, G.S.; DOURADO, P.M.; OLIVEIRA, W.S.; MARTINELLI, S.; BERGER, G.U.; HEAD, G.P.; OMOTO, C. Assessment of the high dose concept and level of control provided by MON
$87701 \times$ MON 89788 soybean against Anticarsia gemmatalis and Pseudoplusia includens (Lepidoptera: Noctuidae) in Brazil. Pest Management Science, v.68, n.7, p.1083-1091, 2012. https:// doi.org/10.1002/ps.3271

BUENO, R.C.O.D.F.; BUENO, A.D.F.; MOSCARDI, F.; POSTALI PARRA, J.R.; HOFFMANN-CAMPO, C.B. Lepidopteran larva consumption of soybean foliage: basis for developing multiplespecies economic thresholds for pest management decisions. Pest Management Science, v.67, p. 170-174, 2011 . https://doi. org/10.1002/ps.2047

CASTRO, M.E.B.; SOUZA, M.L.; SIHLER, W.; RODRIGUES, J.C.M.; RIBEIRO, B.M. Biologia molecular de baculovírus e seu uso no controle biológico de pragas no Brasil. Pesquisa Agropecuária Brasileira. v.34, p.1733-1761, 1999.

CASTRO, M.E.B.; MELO, F.L.; TAGLIARIA, M.; INGLISA, P.W.; CRAVEIRO, S.R.; RIBEIRO, Z.M.A.; RIBEIRO, B.M.; BÁO, S.N. The genome sequence of Condylorrhiza vestigialis NPV, a novel baculovirus for the control of the Alamo moth on Populus spp. in Brazil. Journal of Invertebrate Pathology, v.148, p.152-161, 2017. https://doi.org/10.1016/j.jip.2017.06.013

COMPANHIA NACIONAL DE ABASTECIMENTO (CONAB). Acompanhamento de safra brasileira: grãos, Safra 2017/18 Sétimo levantamento. Brasília: CONAB, 2018. v.7. p.1-139.

COOK, S.P.; WEBB, R.E.; PODGWAITE, J.D.; REARDON, R.C. Increased mortality of gypsy moth Lymantria dispar (L.) (Lepidoptera: Lymantriidae) exposed to gypsy moth nuclear polyhedrosis virus in combination with the phenolic glycoside salicin. Journal of Economic Entomology, v.96, n.6, p.1662-1667, 2003. https:// doi.org/10.1603/0022-0493-96.6.1662

COX, M.E.; AMBORSKI, R.L.; LARSON, A.D. Nuclear polyhedrosis virus of Pseudoplusia includens. Journal of Invertebrate Pathology, v. 19, p.411-413, 1972. 
CRAVEIRO, S.R.; SANTOS, L.A.V.M.; TOGAWA, R.C.; INGLIS, P.W.; GRYNBERG, P.; RIBEIRO, Z.M.A.; RIBEIRO, B.M.; CASTRO, M.E.B. Complete genome sequences of six Chrysodeixis includens nucleopolyhedrovirus isolates from Brazil and Guatemala. Genome Announcements, v.4, n.6, p.e01192-16, 2016. https://doi. org/10.1128/genomeA.01192-16

CRUZ, I.; GONÇALVES, E.P.; FIGUEIREDO, M.L.C. Effect of a nuclear polyhedrosis virus on Spodoptera frugiperda (Smith) (Lepidoptera: Noctuidae) larvae, its damage and yield of maize crop. Revista Brasileira de Milho e Sorgo, v. 1, n.2, p.20-27, 2002. https://doi. org/10.18512/1980-6477/rbms.v1n02p\%25p

DEGRANDE, P.E.; VIVAN, L.M. Pragas da soja. Tecnologia e produção: soja e milho 2008/2009. Maracaju-MS: Fundação MS, 2008. p.73-108.

HAASE, S.; SCIOCCO-CAP, A.; ROMANOWSKI, V. Baculovirus Insecticides in Latin America: historical overview, current status and future perspectives. Viruses, v.7, n.5, p.2230-2267, 2015. https://doi.org/10.3390/v7052230

HERNIOU, E.A.; ARIF, B.M.; BECNEL, J.J.; BLISSARD, G.W.; BONNING, B.; HARRISON, R.; JEHLE, J.A.; THEILMANN, D.A.; VLAK, J.M. Baculoviridae. In: KING, M.J.; ADAMS, E.B. CARSTENS; E.J. LEFKOWITZ. (Eds.). Virus Taxonomy. Oxford: Elsevier, 2012. p.163-174.

KATSUMA, S. Baculovirus controls host caterpillars by manipulating host physiology and behavior. AGri-Bioscience Monographs, v.5, n.1, p. 1-27, 2015. https://doi.org/10.5047/ agbm.2015.00501.0001

KUSS, C.C.; ROGGIA, R.C.R.K.; BASSO, C.J.; OLIVEIRA, M.C.N.; PIAS, O.H.C.; ROGGIA, S. Controle de Helicoverpa armigera (Lepidoptera: Noctuidae) em soja com inseticidas químicos e biológicos. Pesquisa Agropecuária Brasileira, v.51, n.5, p.527-536, 2016. https:// doi.org/10.1590/SO100-204X2016000500013

LACEY, L.A.; UNRUH, T.R. Biological control of codling moth (Cydia pomonella, Lepidoptera: Tortricidae) and its role in integrated pest management, with emphasis on entomopathogens. Vedalia, v.12, n. 1, p.33-60, 2005.

LIVINGSTON, J.M.; MCLEOD, P.J.; YEARIAN, W.C.; YOUNG, S.Y. Laboratory and field evaluation of a nuclear polyhedrosis virus of the soybean looper, Pseudoplusia includens. Journal of Georgia Entomological Society, v.15, n.2, p.194-199, 1980.

MOSCARDI, F. Uso de entomopatógenos no manejo integrado de pragas da soja no Brasil. In: FERNANDES, O.A.; CORREIA, A.C.B.; BORTOLI, S.A. (Eds.). Manejo integrado de pragas e nematoides. Jaboticabal: FUNEP, 1990. chap. 8, p.207-220.

MOSCARDI, F. A nucleopolyhedrovirus for control of the velvetbean caterpillar in Brazilian soybeans. In: MOSCARDI, F. Biological control: a global perspective. Londrina: Embrapa Soybean. p. 344352, 2007. https://doi.org/10.1079/9781845932657.0344

MOSCARDI, F.; SOUZA, M.L.; CASTRO, M.E.B.; MOSCARDI, M.; SZEWCZYK, B. Baculovirus pesticides: present state and future perspectives. In: I. AHMAD, F. AHMAD; J. PICHTEL. (Eds.). Microbes and Microbial Technology. New York: Springer, 201 1. p.415-445.
MOSCARDI, F.; BUENO, A.; SOSA-GÓMEZ, D. R.; ROGGIA, S.; HOFFMANN-CAMPO, C.B.; POMARI, A.F.; CORSO, I.C.; YANO, S.A.C. Artrópodes que atacam as folhas da soja. Soja. Manejo integrado de insetos e outros artrópodes-praga. Brasília, DF: Embrapa, 2012. p.214-334.

PRAÇA, L.B.; SILVA NETO, S.P.; MONNERAT, R.G. Anticarsia gemmatalis Hübner, 1818 (Lepidoptera: Noctuidae) biologia, amostragem e métodos de controle. Brasília: Embrapa Recursos Genéticos e Biotecnologia, 2006. (Documentos, 196).

RITCHIE, S., HANWAY, J.J.; THOMPSON, H.E. How a soybean plant develops. Ames: lowa State University of Science and Technology, Coop. Ext. Serv., 1982. (Special Report, 53).

SANTOS, L.A.V.M.; RIBEIRO, Z.M.A.; GOMES, A.C.M.M.; CRAVEIRO, S.R.; SOARES, C.M.S.; CASTRO, M.E.B. Caracterização morfológica e molecular de isolados virais obtidos de larvas do complexo Heliothinae. Brasília: Embrapa Recursos Genéticos e Biotecnologia, 2016. 26p. (Boletim de Pesquisa e Desenvolvimento, 316 ).

SOSA-GÓMEZ, D.R.; MOSCARDI, F.; SANTOS, B.; ALVES, L.F.A.; ALVES, S.B. Produção e uso de vírus para o controle de pragas na América Latina. In: ALVES, S.B.; LOPES, R.B. Controle Microbiano de Pragas na América Latina: avanços e desafios. Piracicaba: FEALQ, 2008. p. 49-68.

SOSA-GÓMEZ, D.R.; CORRÊA-FERREIRA, B.S.; HOFFMANN-CAMPO, C.B.; CORSO, I.C.; OLIVEIRA, L.J.; MOSCARDI, F.; PANIZZI, A.R.; BUENO, A.F.; HIROSE, E. Manual de identificação de insetos e outros invertebrados da cultura da soja. Londrina: Embrapa Soja, 2014. 90p. (Embrapa Soja. Documentos, 269).

SOUZA, M.L. de; SIHLER, W.; SANCHES, M.M.; SCHMIDT, F.G.V.; BENITO, N.P.; SILVA, M.L. da; FARIA, M.R. de; LOPES, R.B. Ocorrência de Baculovírus em larvas de Chrysodeixis includens em cultivo de soja na Região do Cerrado. Brasília, DF: Embrapa Recursos Genéticos e Biotecnologia, 2015. 19 p. (Embrapa Recursos Genéticos e Biotecnologia. Boletim de Pesquisa e Desenvolvimento, 313).

SPECHT, A.; PAULA-MORAES, S.V.; SOSA-GÓMEZ, D.R. Host plants of Chrysodeixis includens (Walker) (Lepidoptera, Noctuidae, Plusiinae). Revista Brasileira de Entomologia, v.59, n.4, p.343345, 2015. http://dx.doi.org/10.1016/j.rbe.2015.09.002

SRINIVASA, M.; JAGADEESH BABU, C.; ANITHA, C.; GIRISH, G. Laboratory evaluation of available commercial formulations of HaNPV against Helicoverpa armigera (Hub.). Journal of Biopesticides, v.1, n.2, p.138-139, 2008.

SUN, X.L.; PENG, H.Y. Recent advances in biological control of pest insects by using viruses in China. Virologica Sinica, v.22, n.2, p. 158162, 2007. https://doi.org/10.1007/s12250-007-0017-0

THEILMANN, D.A.; BLISSARD, G.W.; BONNING, B.; JEHLE, J.; O'REILLY, D.R.; ROHRMANN, G.F.; THIEM, S.; VLAK, J.M. Baculoviridae. In: MAYO, M.A., MANILOFF, J., DESSELLBERGER, U.; BALL, L.A. (Eds.). Virus taxonomy: classification and nomenclature of viruses. Amsterdam: Elsevier Academic Press, 2005. (Eighth Report of The International Committee on Taxonomy of Viruses).

TRICHILO, P.J.; MACK, T. Soybean leaf consumption by the soybean looper (Lepidoptera: Noctuidae) as a function of temperature, instar and larval weight. Journal of Economic Entomology, v.82, n.2, p.633-638, 1989. https://doi.org/10.1093/jee/82.2.633 
VALICENTE, F.H.; TUELHER, E.S. Controle biológico da lagarta do cartucho, Spodoptera frugiperda, com baculovírus. Sete Lagoas: Embrapa Milho e Sorgo, 2009. 14 p. (Embrapa Milho e Sorgo. Documentos, 114).

VINCENT, C.; ANDERMATT, M.; VALÉRO, J. Madex ${ }^{\circledR}$ and VirosoftCP $4^{\circledR}$, viral biopesticides for codling moth control. In: VINCENT, C.; GOETHEL, M.S.; LAZAROVITS, G. (Eds). Biological control: A global perspective. Cambridge, MA: CAB International, 2007. chap.37, p336-343.
YOUNG, S.Y.; YEARIAN, W.C. Soil application of pseudoplusia npv: persistence and incidence of infection in soybean looper caged on soybean. Environmental Entomology, v.8, n.5, p.860-864, 1979. https://doi.org/10.1093/ee/8.5.860

ZONTA-DE-CARVALHO, R.C.; MOSCARDI, F.; FOERSTER, L.A. Efeito do fungo Nomuraea rileyi (Farlow) Samson e de um vírus de poliedrose nuclear no consumo e na utilização de alimento por Anticarsia gemmatalis Hübner (Lepidoptera: Noctuidae). Anais da Sociedade Entomológica do Brasil, v.20, n.2, p.379-393, 1991. 